\title{
Human Endometrial Stem Cells May Differentiate into Schwann Cells in Fibrin Gel as 3D Culture
}

\author{
Neda Bayat ${ }^{1}$, Somayeh Ebrahimi-Barough2, Mohammad Mehdi Mokhtari Ardakan², \\ Jafar Ai1, ${ }^{*}$ \\ ${ }^{1}$ Brain and Spinal Cord Injury Research Center, Neuroscience Institute, Tehran University of Medical Sciences, \\ Tehran, Iran \\ ${ }^{2}$ Department of Tissue Engineering and Applied Cell Sciences, School of Advanced Technologies in Medicine, \\ Tehran University of Medical Sciences, Tehran, Iran \\ Email: "ebrahimi_s@sina.tums.ac.ir, jafar_ai@tums.ac.ir
}

Received 13 November 2015; accepted 21 December 2015; published 24 December 2015

Copyright @ 2015 by authors and Scientific Research Publishing Inc.

This work is licensed under the Creative Commons Attribution International License (CC BY).

http://creativecommons.org/licenses/by/4.0/

(c) $\underset{\mathrm{EY}}{\mathrm{EY}}$ Open Access

\begin{abstract}
Damage in central nervous system plays an important role in biological life and causes severe paralysis of limbs and some organs. There are solutions to problems that can be a great revolution in the transplanted spinal cord and nerve injuries. Schwann cells (SCs) have important roles in development, myelination and regeneration in the peripheral nervous system. The applications of SCs in regenerative medicine are limited because of slow growth rate and difficulties in harvesting. Critical to the hypothesis is the experimental fact that human endometrial-derived stem cells (hEnSCs) as multipotent accessible source of cells are known as useful cell candidates in the field of nerve tissue engineering. We decided to use the three-dimensional culture of Schwann cells differentiated from endometrial stem cell in fibrin gel. In this study, we investigate the expression of differentiated Schwann cell markers by exposing of endometrial stem cells with induction media including FGF2/FSK/HRG/RA. Using immunocytochemistry, we show that differentiated cells express $\mathbf{S 1 0 0}$ and P75 markers. These results show that for the first time, human endometrial stem cells can be differentiated into Schwann cells in 2D and 3D culture. These novel differentiated cells in fibrin gel might open new opportunities for the management of cell survival and neurotrophic potential in tissue engineering approaches for nerve repair.
\end{abstract}

\section{Keywords}

Endometrial Stem Cell, Schwann Cell, Differentiation, Fibrin Gel, 3D Culture

\footnotetext{
${ }^{*}$ Corresponding author.
}

How to cite this paper: Bayat, N., Ebrahimi-Barough, S., Ardakan, M.M.M. and Ai, J. (2015) Human Endometrial Stem Cells May Differentiate into Schwann Cells in Fibrin Gel as 3D Culture. Neuroscience \& Medicine, 6, 160-164. 


\section{Introduction}

Disruption of neurological structure by injuries to the spinal cord reduces personal motion ability or can lead to paraplegia and death. The CNS can heal and regenerate axons, but the rate is very slow and cannot stop myelin sheath degeneration and cell death especially in the second stage of injury [1]. The limited nature of repair results in functional recovery is being more sporadic than organized. Cell therapy and tissue engineering could provide a therapeutic approach to CNS regeneration [1] [2]. Different cells from various sources under different in vivo condition have been investigated [3]. Tissue engineering provides alternative way for CNS regeneration using cellular transplantation and biomaterial scaffolds [4].

The human endometrial is a dynamic tissue, which undergoes cycles of growth and regression with each menstrual cycle. It is likely that adult stem/progenitor cells are responsible for this remarkable regenerative capacity [5] [6]. It was demonstrated that human endometrium contains a low number of endometrial stem cells which seem to belong to the family of the mesenchymal stem cells [7] [8]. Previous studies have shown the potential differentiation of the endometrial stem cells into chondrogenic and osteoblastic lineages when cultured in appropriate induction medium [9]-[11]. In addition, other studies have shown that stromal cells from endometrial explants can proliferate and then generate new vessels [12] [13]. Since endometrial stromal cells are easy to isolate, and expand rapidly from patients without leading to major ethical and technical problems. Moreover, EnSCs plasticity has been proven by their differentiation along other lineage, such as osteoblast, adipocytes, cardiomyocytes, neuronal, and oligodendrocyte cells [14]-[17]. Therefore, endometrium may be an alternative source of MSC-like cells for tissue engineering purposes, obtainable with no extra morbidity than that required for other sources of stem cells [18]. Nerve injury involves the response of Schwann cells (SCs), the glial cells of the peripheral nervous system, due to remodeling of SC phenotype, and eventually aids the outgrowing axon to reach the target of reinnervation [19]-[21]. For these reasons, SCs were the first cells to be transplanted in bioengineered nerve grafts, thereby improving nerve regeneration; Schwann cells are fundamental for development, myelination and regeneration in the peripheral nervous system [22]-[24]. Slow growth rate and difficulties in harvesting limit SC applications in regenerative medicine [23] [24]. It was shown that various stem cells such as mesenchymal stem cells/marrow stromal stem cells (MSC) and adipose-derived stem cells (ADSC-SCs) had the potential to differentiate into the Schwann cells [25] [26].

In this study, endometrial stromal cells were used as a new source for differentiation to Schwann cells. They were isolated from the donor's tissue; Schwann cells derived from these cells were cultured in fibrin gel. Fibrin has a long history in tissue engineering applications, especially in wound healing. It is a naturally occurring clotting agent in human body, so it has a highly biocompatible scaffold and is easily degraded by enzymes inside the body. Mechanical and chemical properties of this hydrogel can be adjusted by simply changing fibrinogen concentration; also there is an enzymatic crosslinking mechanism that can be easily and harmlessly injected [27].

\section{Hypothesis}

Stem cell therapy has been suggested as a novel treatment for the management of neurodegenerative diseases. The previous studies demonstrated that the pluripotent embryonic stem cells and adult stem cells are capable of differentiating into Schwann cell types which express Schwann-related proteins [28].

Recently, stem cells were isolated from human endometrium, using Schwann differentiation medium. Herein, we postulate that because of the outcome and complication of the other sources of stem cells, stem cell therapy through application of endometrial stem cells can open a new horizon for the treatment of neurodegenerative disorders with lesser degree of complications and better efficacy and outcome [29].

\section{Evaluation of the Hypothesis}

The hypothesis can be evaluated by using flow cytometery for detection of stem cell markers such asCD146, CD90 in the isolated endometrial stem cells. Also, isolated stromal cells will be examined to be free from hematopoietic cells using CD34 staining. The next step is to investigate the ability of human endometrial adult stem cells to differentiate into the Schwann cells showing characteristics of Schwann-like cells (Figure 1). For this purpose, the endometrial stem cells will be induced by Schwann cell differentiation medium. Subsequently, immunocytochemistry will be used for the confirmation of Schwann markers expression such as S100 and P75 in the differentiated cells. 

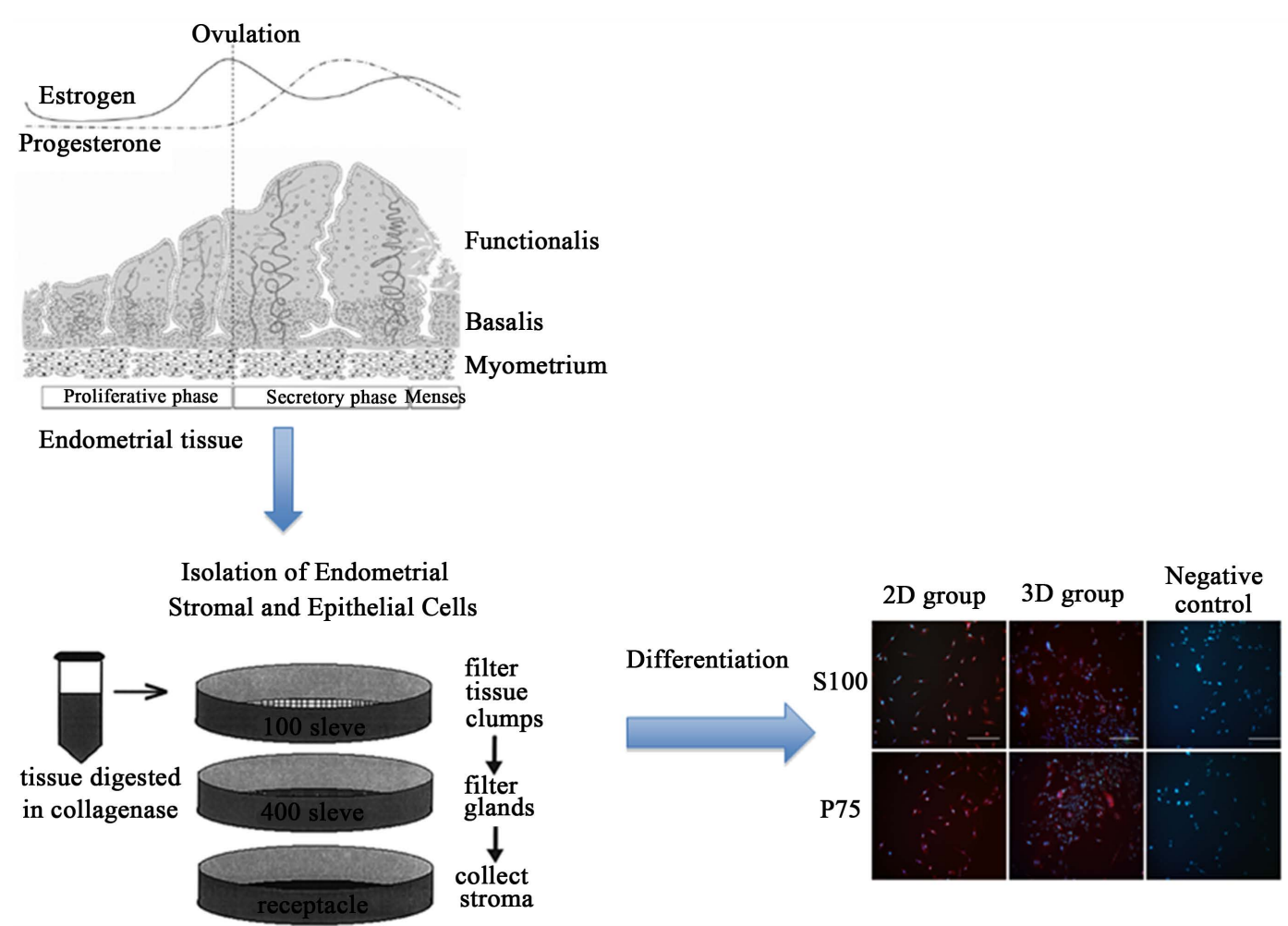

Figure 1. The summery of Schwann cell differentiation of human endometrial stem cells.

Multipotent adult stem/progenitor cells in the endometrium are characterized by a remarkable regenerative capacity of undergoing repetitive cycles of growth and differentiation. Endometrial regenerative cells possess the potential to differentiate into adipocytes, endothelial cells, pancreatic cells and neurons [30]. According previous invaluable experiments, EnSCs have a great potential to differentiate into adipocytes, osteoblasts as well as neurons, and these cells are capable of generating odontoblasts as well as myoblast cells [31] [32]. Thus, it is hypothesized that endometrial adult stem (stromal) cells, could be novel candidates for derivation of Schwann cells, and provide an attractive alternative resource for Schwann cells therapies.

\section{Discussion}

Surgical repair of the peripheral nerve injuries is a frequent clinical problem. For larger nerve defects, transplantation of a nerve graft is often necessary to facilitate nerve regeneration and functional improvement. Alternatives to conventional auto grafts have long been sought because of some problems associated with auto grafts, and the emergence of tissue engineering has greatly stimulated the development of the artificial nerve grafts. It was indicated that the endometrial stem cells displaying excellent multipotent potential [33].

However, the baseline colony forming ability of the endometrial stromal cells is comparable to most enriched bone marrow MSC populations [34] [35]. Endometrial stromal cells can be obtained by a simple, safe and painless procedure in contrast to bone marrow aspiration. These cells have higher clonogenicity and can be obtained from elderly donors because other cell source such as bone marrow MSCs loss their differentiation capacity significantly with increased donor age. It may be concluded that the endometrial stem cells in the treatment of neuronal disorders are more convenient than other sources of stem cells.

\section{Conclusion}

In the past few years, for neurodegenerative diseases therapy, research has focused on the stem cells therapy. Due to promising results in stem cell therapy, there are different sources of stem cells for transplantation in human. Recently, a highly promising source of accessible, abundant and multipotent adult stem cells is human endometrial stem cells. Consequently, we hypothesize that endometrial adult stem cells can differentiate into 
Schwann cells when they are exposed to specific differentiated conditions. These stem cells have potential advantages over other stem cells and are attractive candidate for nervous system regeneration.

\section{Conflict of Interest}

None declared.

\section{References}

[1] Gu, X.S., Ding, F., Yang, Y.M. and Liu, J. (2011) Construction of Tissue Engineered Nerve Grafts and Their Application in Peripheral Nerve Regeneration. Progress in Neurobiology, 93, 204-230. http://dx.doi.org/10.1016/j.pneurobio.2010.11.002

[2] Yazdankhah, M., Farioli-Vecchioli, S., Tonchev, A.B., Stoykova, A. and Cecconi, F. (2014) The Autophagy Regulators Ambra1 and Beclin 1 Are Required for Adult Neurogenesis in the Brain Subventricular Zone. Cell Death and Disease, 5, e1403. http://dx.doi.org/10.1038/cddis.2014.358

[3] Koda, M., Okada, S., Nakayama, T., Koshizuka, S., Kamada, T., Nishio, Y. and Someya Y. (2005) Hematopoietic Stem Cell and Marrow Stromal Cell for Spinal Cord Injury in Mice. Neuroreport, 16, 1763-1767. http://dx.doi.org/10.1097/01.wnr.0000183329.05994.d7

[4] Khaing, Z.Z. and Schmidt, C.E. (2012) Advances in Natural Biomaterials for Nerve Tissue Repair. Neuroscience Letters, 519, 103-114. http://dx.doi.org/10.1016/j.neulet.2012.02.027

[5] Gargett, C.E., Chan, R.W. and Schwab, K.E. (2007) Endometrial Stem Cells. Current Opinion in Obstetrics \& Gynecology, 19, 377-383. http://dx.doi.org/10.1097/gco.0b013e328235a5c6

[6] Jabbour, H.N., Kelly, R.W., Fraser, H.M. and Critchley, H.O. (2006) Endocrine Regulation of Menstruation. Endocrine Reviews, 27, 17-46.

[7] Dimitrov, R., Timeva, T., Kyurkchiev, D., Stamenova, M., Shterev, A., Kostova, P., Zlatkov, V., Kehayov, I. and Kyurkchiev, S. (2008) Characterization of Clonogenic Stromal Cells Isolated from Human Endometrium. Reproduction, 135, 551-558. http://dx.doi.org/10.1530/REP-07-0428

[8] Harirchian, M.H., Tekieh, A.H., Modabbernia, A., Aghamollaii, V., Tafakhori, A., Ghaffarpour, M., Sahraian, M.A., Naji, M. and Yazdankhah, M. (2012) Serum and CSF PDGF-AA and FGF-2 in Relapsing-Remitting Multiple Sclerosis: A Case-Control Study. European Journal of Neurology, 19, 241-247. http://dx.doi.org/10.1111/j.1468-1331.2011.03476.x

[9] Gargett, C.E. (2006) Identification and Characterization of human Endometrial Stem/Progenitor Cells. Australian and New Zealand Journal of Obstetrics and Gynaecology, 46, 250-253.

http://dx.doi.org/10.1111/j.1479-828X.2006.00582.x

[10] Niknamasl, A., Ostad, S.N., Soleimani, M., Azami, M., Salmani, M.K., Lotfibakhshaiesh, N., Ebrahimi-Barough, S., Karimi, R., Roozafzoon, R. and Ai, J. (2014) A New Approach for Pancreatic Tissue Engineering: Human Endometrial Stem Cells Encapsulated in Fibrin Gel Can Differentiate to Pancreatic Islet Beta-Cell. Cell Biology International, 38, 1174-1182. http://dx.doi.org/10.1002/cbin.10314

[11] Schwab, K.E., Hutchinson, P. and Gargett, C.E. (2008) Identification of Surface Markers for Prospective Isolation of Human Endometrial Stromal Colony-Forming Cells. Human Reproduction, 23, 934-943. http://dx.doi.org/10.1093/humrep/den051

[12] Ebrahimi-Barough, S., Hoveizi, E., Norouzi Javidan, A. and Ai, J. (2015) Investigating the Neuroglial Differentiation Effect of Neuroblastoma Conditioned Medium in Human Endometrial Stem Cells Cultured on 3D Nanofibrous Scaffold. Journal of Biomedical Materials Research Part A, 103, 2621-2627. http://dx.doi.org/10.1002/jbm.a.35397

[13] Khazaei, M., Esfandiari, N., Gotlieb, L. and Casper, R.F. (2004) Angiogenesis Following Three-Dimensional Culture of Isolated Human Endometrial Stromal Cells. Fertility and Sterility, 82, S61-S62. http://dx.doi.org/10.1016/j.fertnstert.2004.07.157

[14] Ai, J., Shahverdi, A.R., Ebrahimi-Barough, S., Kouchesfehani, H.M., Heidari, S., Roozafzoon, R., Verdi, J. and Khoshzaban, A. (2012) Derivation of Adipocytes from Human Endometrial Stem Cells (EnSCs). Journal of Reproduction \& Infertility, 13, 151-157.

[15] Ebrahimi-Barough, S., Norouzi Javidan, A., Saberi, H., Joghataei, M.T., Rahbarghazi, R., Mirzaei, E., Faghihi, F., Shirian, S., Ai, A. and Ai, J. (2015) Evaluation of Motor Neuron-Like Cell Differentiation of hEnSCs on Biodegradable PLGA Nanofiber Scaffolds. Molecular Neurobiology, 52, 1704-1713. http://dx.doi.org/10.1007/s12035-014-8931-2

[16] Bockeria, L., Bogin, V., Bockeria, O., Le, T., Alekyan, B., Woods, E.J., Brown, A., Ichim, T.E. and Amit, P. (2013) Endometrial Regenerative Cells for Treatment of Heart Failure: A New Stem Cell Enters the Clinic. Journal of Translational Medicine, 11, 56. http://dx.doi.org/10.1186/1479-5876-11-56 
[17] Ebrahimi-Barough, S., Massumi, M., Kouchesfahani, H.M. and Ai, J. (2013) Derivation of Pre-Oligodendrocytes from Human Endometrial Stromal Cells by Using Overexpression of microRNA 338. Journal of Molecular Neuroscience, 51, 337-343. http://dx.doi.org/10.1007/s12031-013-0101-x

[18] Stenderup, K., Justesen, J., Clausen, C. and Kassem, M. (2003) Aging Is Associated with Decreased Maximal Life Span and Accelerated Senescence of Bone Marrow Stromal Cells. Bone, 33, 919-926. http://dx.doi.org/10.1016/j.bone.2003.07.005

[19] Mirsky, R. and Jessen, K.R. (1999) The Neurobiology of Schwann Cells. Brain Pathology, 9, 293-311. http://dx.doi.org/10.1111/j.1750-3639.1999.tb00228.x

[20] Chen, Z.L., Yu, W.M. and Strickland, S. (2007) Peripheral Regeneration. Annual Review of Neuroscience, 30, $209-233$. http://dx.doi.org/10.1146/annurev.neuro.30.051606.094337

[21] Ide, C. (1996) Peripheral Nerve Regeneration. Neuroscience Research, 25, 101-121. http://dx.doi.org/10.1016/0168-0102(96)01042-5

[22] Guenard, V., Kleitman, N., Morrissey, T.K., Bunge, R.P. and Aebischer, P. (1992) Syngeneic Schwann Cells Derived from Adult Nerves Seeded in Semipermeable Guidance Channels Enhance Peripheral Nerve Regeneration. The Journal of Neuroscience, 12, 3310-3320.

[23] Mosahebi, A., Fuller, P., Wiberg, M. and Terenghi, G. (2002) Effect of Allogeneic Schwann Cell Transplantation on Peripheral Nerve Regeneration. Experimental Neurology, 173, 213-223. http://dx.doi.org/10.1006/exnr.2001.7846

[24] Mosahebi, A., Woodward, B., Wiberg, M., Martin, R. and Terenghi, G. (2001) Retroviral Labeling of Schwann Cells: in Vitro Characterization and in Vivo Transplantation to Improve Peripheral Nerve Regeneration. Glia, 34, 8-17. http://dx.doi.org/10.1002/glia.1035

[25] Ortiz-Gonzalez, X.R., Keene, C.D., Verfaillie, C.M. and Low, W.C. (2004) Neural Induction of Adult Bone Marrow and Umbilical Cord Stem Cells. Current Neurovascular Research, 1, 207-213. http://dx.doi.org/10.2174/1567202043362342

[26] Dhara, S.K. and Stice, S.L. (2008) Neural Differentiation of Human Embryonic Stem Cells. Journal of Cellular Biochemistry, 105, 633-640. http://dx.doi.org/10.1002/jcb.21891

[27] Le, N., Damien, L., Guehennec, L., Rouillon, T., Pilet, P., Bilban, M., Layrolle, P. and Daculsi, G. (2006) Micro-Architecture of Calcium Phosphate Granules and Fibrin Glue Composites for Bone Tissue Engineering. Biomaterials, 27, 2716-2722. http://dx.doi.org/10.1016/j.biomaterials.2005.11.038

[28] Ai, J. and Mehrabani, D. (2010) Are Endometrial Stem Cells Novel Tools against Ischemic Heart Failure in Women? A Hypothesis. Iranian Red Crescent Medical Journal, 12, 73-75.

[29] Montzka, K., Lassonczyk, N., Tschöke, B., Neuss, S., Führmann, T., Franzen, R., Smeets, R., Brook, G.A. and Wöltje, M. (2009) Neural Differentiation Potential of Human Bone Marrow-Derived Mesenchymal Stromal Cells: Misleading Marker Gene Expression. BMC Neuroscience, 10, 16. http://dx.doi.org/10.1186/1471-2202-10-16

[30] Meng, X., Ichim, T.E., Zhong, J., Rogers, A., Yin, Z., Jackson, J., et al. (2007) Endometrial Regenerative Cells: A Novel Stem Cell Population. Journal of Translational Medicine, 5, 57. http://dx.doi.org/10.1186/1479-5876-5-57

[31] Ai, J., Tabatabaei, F. and Jafarzadeh Kashi, T. (2009) Human Endometrial Adult Stem Cells May Differentiate into Odontoblast Cells. Hypothesis, 7, e6. http://dx.doi.org/10.5779/hypothesis.v7i1.152

[32] Ai, J., Tabatabaei, F. and Kajbafzadeh, A.M. (2009) Myogenic Potential of Human Endometrial Adult Stem Cells. Iranian Journal of Medical Hypotheses and Ideas, 3, 25.

[33] Baggish, M., Pauerstein, C. and Woodruff, J. (1967) Role of Stroma in Regeneration of Endometrial Epithelium. American Journal of Obstetrics \& Gynecology, 99, 459-465. http://dx.doi.org/10.1016/0002-9378(67)90291-8

[34] Deschaseaux, F. and Charbord, P. (2000) Human Marrow Stromal Precursors Are $\alpha 1$ Integrin Subunit-Positive. Journal of Cellular Physiology, 184, 319-325. http://dx.doi.org/10.1002/1097-4652(200009)184:3<319::AID-JCP5>3.0.CO;2-N

[35] Buhring, H.J., Battula, V., Treml, S., Schewe, B., Kanz, L. and Vogel, W. (2007) Novel Markers for the Prospective Isolation of Human MSC. Annals of the New York Academy of Sciences, 1106, 262-271. http://dx.doi.org/10.1196/annals.1392.000 